Ibrahim Dincer · Adnan Midilli Haydar Kucuk Editors

Progress in

Sustainable Energy

Technologies Vol II

Creating Sustainable Development

Springer 


\author{
Editors \\ Ibrahim Dincer \\ Department of Mechanical Engineering \\ University of Ontario Institute \\ of Technology \\ Oshawa, ON, Canada
}

\author{
Haydar Kucuk \\ Department of Mechanical Engineering \\ Faculty of Engineering \\ Recep Tayyip Erdoğan University \\ Rize, Turkey
}

\author{
Adnan Midilli \\ Department of Mechanical \\ Engineering \\ Recep Tayyip Erdoğan University \\ Rize, Turkey
}

ISBN 978-3-319-07976-9

ISBN 978-3-319-07977-6 (eBook)

DOI 10.1007/978-3-319-07977-6

Springer Cham Heidelberg New York Dordrecht London

Library of Congress Control Number: 2014941874

(C) Springer International Publishing Switzerland 2014

This work is subject to copyright. All rights are reserved by the Publisher, whether the whole or part of the material is concerned, specifically the rights of translation, reprinting, reuse of illustrations, recitation, broadcasting, reproduction on microfilms or in any other physical way, and transmission or information storage and retrieval, electronic adaptation, computer software, or by similar or dissimilar methodology now known or hereafter developed. Exempted from this legal reservation are brief excerpts in connection with reviews or scholarly analysis or material supplied specifically for the purpose of being entered and executed on a computer system, for exclusive use by the purchaser of the work. Duplication of this publication or parts thereof is permitted only under the provisions of the Copyright Law of the Publisher's location, in its current version, and permission for use must always be obtained from Springer. Permissions for use may be obtained through RightsLink at the Copyright Clearance Center. Violations are liable to prosecution under the respective Copyright Law.

The use of general descriptive names, registered names, trademarks, service marks, etc. in this publication does not imply, even in the absence of a specific statement, that such names are exempt from the relevant protective laws and regulations and therefore free for general use.

While the advice and information in this book are believed to be true and accurate at the date of publication, neither the authors nor the editors nor the publisher can accept any legal responsibility for any errors or omissions that may be made. The publisher makes no warranty, express or implied, with respect to the material contained herein.

Printed on acid-free paper

Springer is part of Springer Science+Business Media (www.springer.com) 


\section{Contents}

$1 \quad$ Energy and Exergy Analyses of an Active Magnetic Refrigerator....................... 1 Hadi Ganjehsarabi, Ibrahim Dincer, and Ali Gungor

2 Evaluation of Sustainable Energy Options for Non-residential

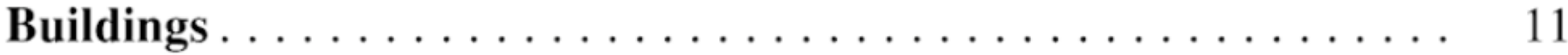

Behnaz Rezaie, Ibrahim Dincer, and Ebrahim Esmailzadeh

3 Exergoeconomic and Enviroeconomic Analyses of Hybrid Electric Vehicle Thermal Management Systems . . . . . . . . . 35 H.S. Hamut, I. Dincer, and G.F. Naterer

4 CFD Analysis of a Shell and Tube Heat Exchanger Linking a Supercritical Water-Cooled Nuclear Reactor and a Copper-Chlorine Hydrogen Production Cycle . . . . . . . . 55 Ali H. Abedin, Murat Aydin, and Marc A. Rosen

5 Entropy Generation of Hydrogen Flow in a Curved Annular Duct . . . . . . . . . . . . . . . . . . . . . . . . . . 63

Haydar Kucuk, Ugur Akbulut, and Adnan Midilli

6 Influence of Turbine Inlet Temperature on the Efficiency of Externally Fired Gas Turbines . . . . . . . . . . . . . . . . . . . . 79 Paulo Eduardo Batista de Mello, Sérgio Scuotto, Fernando dos Santos Ortega, and Gustavo Henrique Bolognesi Donato

7 Exergy and Exergo-Economic Based Analysis of a Gas Turbine Power Generation System . 
8 Non Repeating Thermal Bridges and the Impact on Overall Heating Energy Consumption in a Typical UK Home . . . . . . . . . . 109 Hasim Altan and Young Ki Kim

9 An Evaluation of Indoor Environment in Deprived Community Housing in Yorkshire and the Humber Region of England, UK Hasim Altan and Mohamed Refaee

10 The Application of Phase Change Materials to Improve the Climate Resilience of a Low-Energy Prototype House . . . . . .

Lucelia Rodrigues, David Tetlow, Mark Gillott, and Vasileios Sougkakis

11 Green Jubail Industrial City

Mohammed I.Y. Aleid

12 Design of a Nearly Zero Energy One-Family House in North-Centre Italy

Enzo Zanchini and Stefano Lazzari

13 Integrative Approach for Desert Sustainable Ecohouse Design . . .

Khaled A. Al-Sallal and Iman K. Al-Sallal

14 Ventilation and Architectural Design Strategies for Cooling Office Buildings in Different Climates of Chile . . . . . . 203 Waldo Bustamante Gómez, Felipe Encinas Pino,

Sergio Vera Araya, and Francisco Sánchez de la Flor

15 Investigations for the Thermal Influence of Glass Patterns on the Building Envelope . . . . . . . . . . . . . . . . . . 213 Shiang-Jiun Lin, Yong-Cheng Chen, and Po-Tao Sun

16 Choosing the Right Technology: Optimized Design of Renewable Supply Systems for Residential Houses . . . . . . . . . 227 Christian Milan, Mads Pagh Nielsen, and Carsten Bojesen

17 State of the Art Review: Fuel Cell Technologies in the Domestic Built Environment .

Theo Elmer and Saffa B. Riffat

18 Green Lab: A Strategic Design Framework to Develop Sustainable Research Laboratories . . . . . . . . . . . . . . . . 273 Rosalba Belibani, Elena Gigliarelli, and Jody Patterson

19 Integrated System Concept for Energy Efficient Smart

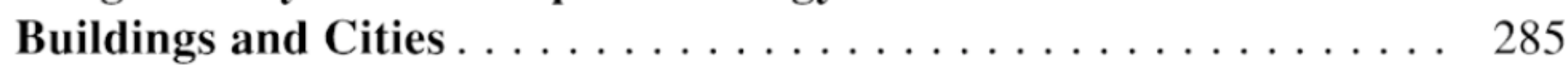
Hasan Ufuk Gökçe and Kamil Umut Gökçe 
20 Interoperable ICT Platform for Energy Efficient Smart Buildings . . . . . . . . . . . . . . . . . . . . . . . . . . . 299 Hasan Ufuk Gökçe and Kamil Umut Gökçe

21 Software Interoperability for Energy Efficient Building Operations Based on the IFC Data Model Standard . Hasan Ufuk Gökçe and Kamil Umut Gökçe

22 Virtual Energy Platform for Low Energy Building Operations . . . 319 Hasan Ufuk Gökçe and Kamil Umut Gökçe

23 The Studies of Environmental Ionizing Radiation Curriculum Indicators for Taiwan's Elementary and Junior High School. .

Chien-kuo Ku and Cheng Da Wu

24 An Energy Strategy in a Liberalized Environment in Slovakia .

Milena Sviteková, Henrieta Pavolová, and Barbara Hlavňová

25 Towards an Integrated Value Optimizing Ecosystem in Natural Gas Liquids Operations and Related Facilities . . . . . . 369 Farayi Musharavati

26 Mass Transfer and Bubble Flow Dynamics in Aqueous Solutions for Hydrogen Production Cycles .

O.A. Jianu, M.A. Rosen, G.F. Naterer, and Z. Wang

27 Numerical Analysis of the Thermo-mechanical Behavior of Energy Piles .

Heng Zhao, Ping Cui, Lin Lu, and Zhaohong Fang

28 An Equivalent-Capacitance Approach for Determining the Performance of a Refrigerant Coil .

Chun Kwong Lee and Hong Nam Lam

29 Perspectives on Sustainability in Natural-Gas-Liquids Operations Through a Cleaner Production Framework

Reem Fahd and Farayi Musharavati

30 Energy Savings Through Applications of Lean Manufacturing Principles .

Roba Salim, Buthaina Ali, and Farayi Musharavati

31 Empirical Formulation of Shear Modulus Functions for Tubular Pinewood Specimens Under Torsion

Ezgi Günay, Cevdet Aygün, and Emre Uludoğan 
32 Robust Control Techniques of ASVC-Based Var Flow

Compensation . . . . . . . . . . . . . . . . . . . . . . . . . . . . . . . . . . . 489

Mansour Benyamina and Benyounes Mazari

33 Thermogravimetric Studies on Co-combustion

Characteristics of Mengxi Coal and Poplar . . . . . . . . . . . . . . 503

Kaiqi Shi, Tao Wu, Jiefeng Yan, Haitao Zhao,

Philip Hall, and Edward Lester

34 High-Performance Recycling System for Waste

Plastics Using Raman Identification . . . . . . . . . . . . . . . . . . . 519

Hirofumi Kawazumi, Akihiro Tsuchida, Tomoya Yoshida, and Yasuo Tsuchida

35 Clean Combustion of Low Quality Fuel in Fluidized

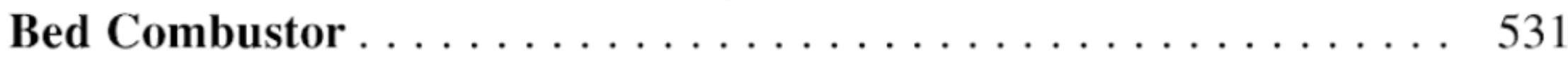

Rami S. El-Emam, Farouk M. Okasha, and Salah H. El-Emam

36 Theoretical and Experimental Study of a Novel Film

Evaporation Cooling System . . . . . . . . . . . . . . . . . . . . . . . 547

Hooman Golchoobian, Mohamad Hasan Taheri,

Majid Amidpour, and Omid Pourali

37 Environmental Friendly Food Smoking Technologies

Aydin Killic, Haydar Kucuk, and Adnan Midilli

38 Impact of Shape, Occupation and External Parameters in the Overall Thermal Performance of Office Buildings

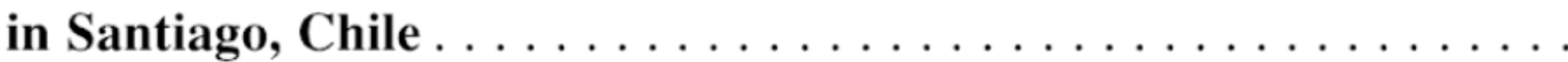

Claudio Vásquez, Alejandro Prieto, and Carlos Aguirre

39 Multisource Heat Pump System: The Case Study of a New School Building.

Marco Noro, Renato Lazzarin, and Filippo Busato

40 Application of Heat Pipe System in Data Center Cooling . Xiaodong Qian, Zhen Li, and Hao Tian

41 Energy and Exergy Analysis of a Trigeneration Facility with Natural Gas Engine .

Emin Acikkalp, Ozgur Balli, Hasan Yamik, and Haydar Aras

42 Numerical Study of Solidification in Triplex Tube

Heat Exchanger .

Abduljalil A. Al-Abidi, Sohif Mat, K. Sopian,

M.Y. Sulaiman, and Abdulrahman Th. Mohammad 
43 Computer Simulation of Heat and Mass Transfer in a Cross Flow Parallel-Plate Liquid Desiccant-Air Dehumidifier . . . . . . . . . . . . . . . . . . . . . . . . . . . . . . . . . . . 649 Abdulrahman Th. Mohammad, Sohif Bin Mat, M.Y. Sulaiman, Kamaruzzaman Sopian, and Abduljalil A. Al-abidi

44 Experimental Study of the Heat Transfer Performance of PCMs Within Metal Finned Containers . . . . . . . . . . . . . . . 669 Yongcai Li, Shuli Liu, and Yaqin Zhang

45 Simulation of Double Effect Absorption Refrigeration System . . . 685 Ibrahim Atilgan and Cevdet Aygun

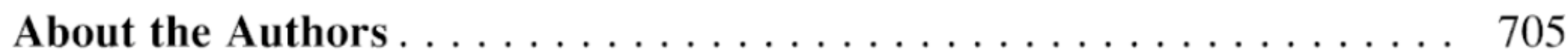

Index . . . . . . . . . . . . . . . . . . . . . . . . 707 


\title{
Chapter 18 \\ Green Lab: A Strategic Design Framework to Develop Sustainable Research Laboratories
}

\author{
Rosalba Belibani, Elena Gigliarelli, and Jody Patterson
}

\begin{abstract}
The aim of this paper is to present a system of design strategies, useful to technical institutes and universities, that endeavor to create more environmentally and socially sustainable laboratory spaces.

The Green Lab model is designed to promote sustainable education throughout the complete life cycle of smart buildings. This requires a critical departure from traditional practices, starting at the formative stage, as defined by Edward Mazria's 2010 Imperative and 2030 Challenge (http://architecture2030.org/): first the change required in education, making ecological literacy a central tenet; then the change enabled in design, required to reduce $\mathrm{CO}_{2}$ emissions by building activity by $50 \%$. Green Lab assumes an alternative approach to design education, to deliver different results-rendering the education process itself innovative, interactive and sustainable, and demanding smart buildings with the same characteristics.

The Green Lab methodology has been developed through teaching and research experience, providing a forum to apply and test design principles and innovative construction technologies as well as an occasion to propose a shift in cultural paradigm, so that university and research institutions themselves become prototypes in the field of sustainable building and energy technologies. The building project must constitute an innovation epicenter for the study of sustainable technologies, representing in itself a testing ground for advanced "solutions in progress" which are continually integrated, evaluated and replaced.

The result of this sustainable education model is the design of an architectural organism conceived according to bioclimatic strategies for minimal environmental impact, using recycled materials and meeting the highest standards of energy
\end{abstract}

\author{
R. Belibani Ph.D. (西) \\ "Sapienza" Università di Roma, Roma, Italy \\ e-mail: rosalba.belibani@uniroma1.it \\ E. Gigliarelli \\ ITABC, CNR National Research Institute, Bologna, Italy \\ e-mail: elena.gigliarelli@itabc.cnr.it \\ J. Patterson \\ University of Waterloo, Waterloo, ON, Canada N2L 3G1 \\ e-mail: japatterson@uwaterloo.ca
}


efficiency - a Green Lab capable of sustaining itself, generating energy from renewable sources via its form, surfaces and volumes. The knowledge base of the design laboratory is in constant expansion, requiring active research contributions (via dedicated website DiarAmbiente) from all participants: students, professors, architects, engineers, and national researchers collaborate directly to maintain a highly dynamic multilateral learning environment, keeping the moving target of sustainable design in focus. Its outcomes are high-level design projects, demonstrating increased consciousness and commitment to sustainable building.

Keywords Sustainable education $\bullet$ Design studio $\bullet$ Research project $\bullet$ Green Lab

- Adaptive reuse

\subsection{Background}

The initiative to start a research project within a design studio context-founded upon the themes, methodology, content and goals of sustainability educationcame after a long process of enhancing ecological literacy in collaboration with Anna Gadola and Franca Bossalino, and expressed in the research published on the website DiarAmbiente [1].

In May 2005, American architect Edward Mazria challenged the international building community to take the lead in combating climate change. In June 2005, sixteen of the most important institutions worldwide in the field of architectural education signed the Declaration of Las Vegas, recognizing "the great responsibility that rests on the architectural profession to do everything possible to influence a significant reduction carbon emissions resulting from construction and the life cycle of the built environment."

In 2006, Mazria launched Imperative 2010 online-regarding the change required in education, whereby ecological literacy must become a central tenet of design education-along with the 2030 Challenge [2], to change building design in order to achieve a $50 \%$ reduction in the level of $\mathrm{CO}_{2}$ emissions produced by the building industry. The DiarAmbiente site was born thus, with the conviction that we can develop all of our theories into practical application within the Design Studios of the Architectural and Urban Design program, held for 2 years, within the 5-year degree course in Architecture of the EU at the Faculty of Architecture at Sapienza University of Rome.

\subsection{Problem}

It was decided to target the entire design studio experience-both teaching and learning-in order to integrate and develop the complex aspects of sustainability. The most difficult challenge to approach was to conceive a teaching methodology 
that could be called sustainable within the context of the teaching tradition, coexisting with the difficulties inherent to the teaching discipline. The design exercises to be assigned to students were more easily identified and treated in an articulated manner:

- 'Ecological literacy' education as a central principle in ecological design project, aiming to reduce $\mathrm{CO}_{2}$ emissions by $50 \%$.

- Deepening of technological and engineering aspects within an architectural language where form follows not function, but the evolution of the project.

- Analysis of the relationships between the project and its locality.

- Technical analysis of the composition process, highlighting the complexity of the design process wherein practical skills and theory must feed each other.

- Attention to all aspects of the environmental sustainability of the project which inform the architectural solution.

The final design project assigned was a scientific research laboratory facility, characterized as an artificial lung, with a contemporary and technologically advanced architectural structure, to be achieved on the site of the National Research Council of Rome (CNR) in the municipality of Montelibretti: a scientific campus of 70 ha, including 15 institutes and over 500 employees.

To ensure realistic adherence to the aims of the project, the teaching staff was enhanced with the participation of Arch. Luciano Cessari and Arch. Elena Gigliarelli, both of CNR-ITABC, and Jody A. Patterson, Visiting Professor at the Faculty of Architecture, as well as other staff with experience in teaching design, sustainability and sustainability assessment via LEED and ITACA protocols.

The assignment was to design an architectural organism, incorporating recyclable materials and the latest solutions for reducing energy use and implementing energy from renewable sources, characterized as a "green laboratory": a Green Lab with low environmental impact, which can sustain itself from an energy standpoint. The building must be a center for the study of innovative technologies in sustainability, applied to the understanding, conservation and renovation of our built heritage, representing in itself a prototype "in progress" for technologically advanced solutions, to be continuously integrated or replaced.

\subsection{Context}

Redeveloping an area of the National Research Council site was, therefore, the issue addressed in the Design Studio, for which students were encouraged to experiment with the design of new models of buildings for researchers and scientists, utilizing the latest solutions for energy saving and use of energy from renewable sources.

Teaching goals were established to elaborate a joint project, accomplished through a complex systems approach, to create new workspaces for scholars and researchers while at the same time leading to the improvement and enhancement- 
on an environmental, landscape and architecture basis - of this important Italian Science and Technology Park. The aim of this design project is to improve the quality of research and sustainability of the entire complex, via a systematic and coherent set of interventions on existing buildings, open and green spaces, but also to develop a model for science parks (CNR research area of Rome) that encourages cooperation between public research universities, public and private industry. Research laboratories so designed can encourage interaction between scientists from various disciplines, promote the recruitment of top researchers and facilitate the association and development of scientific activities. The challenge in designing a laboratory for scientific research contained in a contemporary and technologically advanced architectural organism, involved the creation of a self-sustaining low-impact "Green Lab."

\subsection{Approach}

The design studio, which aims to provide students with the theoretical knowledge and practical skills necessary for project development, is traditionally organized into lectures, exercises and design activities in the classroom. Usually, the student is a passive subject during lessons and intervenes only during reviews, showing the progress of their project. To transform, therefore, the design studio into an educational experiment - as sustainable as possible — we attempted to shift the student into an active role, taking a share in the teaching work from which the student is traditionally excluded. Sustainable design issues approached during the course were developed through the following activities:

- Three interim hand-ins of maquettes at different scales.

- Various tutorials on complex topics agreed with or chosen by the student.

- Presentation of systems for assessing the sustainability of a project, both specific to Italy (ITACA) and international (LEED), applied as an analysis exercise to projects chosen by the student.

- Ongoing reviews to check the progress of individual projects and permit a more personal relationship between teacher and student.

Students were also required to keep a studio album in which to collect notes, drawings, thoughts, ideas, sketches, impressions, images, references to other projects or specific theoretical references.

Two introductory lectures were delivered by Professor Franca Bossalino, long engaged in a campaign to improve the ecological literacy of architecture students. Within the Architectural and Urban Design IV studio, which served as a testing ground for this new approach to sustainability as applied to didactic activity and content, there are two Training Modules (approximately $30 \mathrm{~h}$ each) of "Systems" and "Technologies," which, in applying a structured model for sustainable education, offered substantial contributions to the development of an integrated design project. 
The architectural project was developed during three intense months, taking a holistic approach and applying bioclimatic design processes governed by effective elements and best-practice solutions for sustainable design (buffer zones, curtain walls, green roofs, green walls, use of geothermal energy, appropriate use of integrated solar panels, etc.) The course website also provided a means to share the extensive and detailed bibliography and an notable collection of web-links with important information for project development.

\subsection{Methodology}

Studio teaching was approached as an experiment to define a design methodology around innovative and sustainable laboratories, to be implemented at a Science Park operated by Italy's most significant research agency. Choosing the CNR Rome site for the Studio intervention gives strict boundaries to the development of the theme, based in thorough analysis of the context and the scale of the intervention area. An environment of 70 acres at high landscape value, veined with a network of laboratories and scientific institutions developed in various phases over 40 years, posed the problem of supporting critical functionality of these headquarters while enhancing the area as a green and attractive place for research excellence: seeking an architectural intervention that can begin a process of regeneration of the entire campus.

The theme of the redevelopment of the site thereby intersected with a teaching methodology aiming to develop sustainable solutions and models for a new type of research laboratory, a "social incubator" that encourages interaction and teambased research, while providing the flexibility to allow ongoing evolution and change (Fig. 18.1).

Departing from the classical approach of functional laboratory, the research site was no longer seen as a machine for the development of techno-scientific processes but as a place of intellectual work and open and flexible experiments, connected to social and scientific networks and populated by "nomadic workers," operating within a crowd sourcing framework that foresees the collaboration of many researchers who via these networks will accomplish a particular job-all of this with obvious reflections on building design and architectural solutions.

It was therefore requested that the proposed project express levels of in-depth research and design on the following topics:

1. A Green Lab, called "LARIS Laboratory for Interactive Research on Sustainability."

2. A Science Center.

3. The archaeological museum display area of Colle del Forno. 


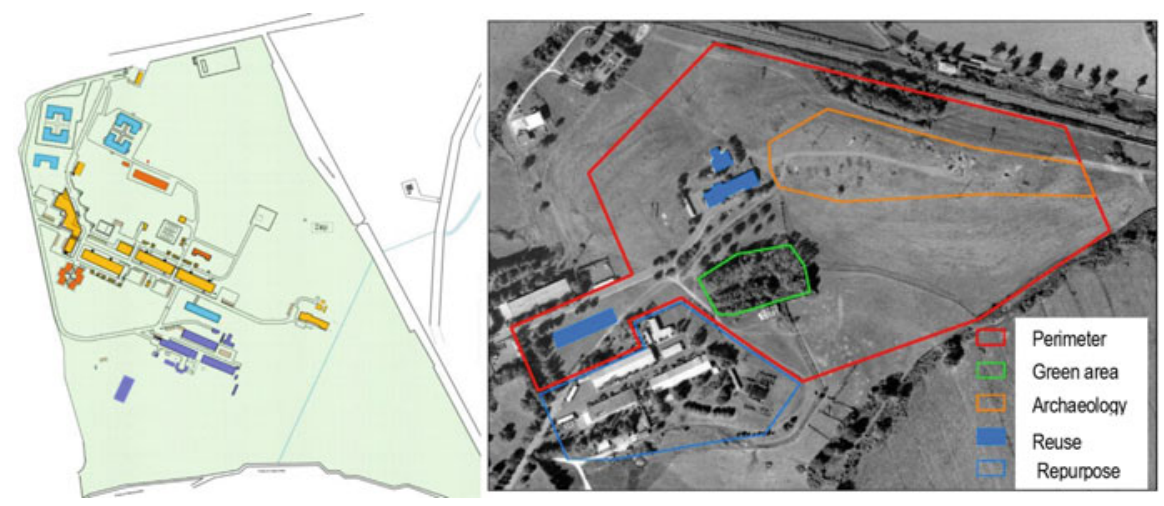

Fig. 18.1 Master plans

\subsubsection{LARIS Green Lab}

The LARIS Green Lab was thought of as a 'living laboratory' in which researchers and partners in conservation can carry out research and evaluation on current and future systems and technologies at a high degree of performance and sustainability. In this sense LARIS will be used as a platform to test and demonstrate the technical performance and usability features of their technologies and systems. Product evaluation (via technical analysis and compatibility testing) performed by an independent public research entity can reduce the public burden of product development and create early market demand. Advanced visualization systems and simulation technologies will be used to involve all those involved in conservation efforts for built heritage (architects, restorers, superintendents, manufacturers of environmentally sustainable materials, etc.) (Fig. 18.1).

\subsubsection{Science Center}

The architectural organism assigned also had to include a Science Center, able to promote the dissemination of scientific research findings and discoveries in the very facility and in the field of sustainability, as well as those developed in other institutions in the area. This "Thematic Center" was to open to the public the contents of discoveries and innovations in this field, proposing itself as a platform for communication and exchange between the institute and the scientific community. To satisfy these needs, a room for multimedia exhibit was also requested for the display and dissemination of scientific culture: a place to perform interactive simulations of the performance and use of the building and explore alternative scenarios with sustainable strategies. This should include: a multimedia theater featuring advanced visualization (high-quality, high-scale screens to exhibit graphics and audio) and technologies of interaction with the public; reconfigurable 

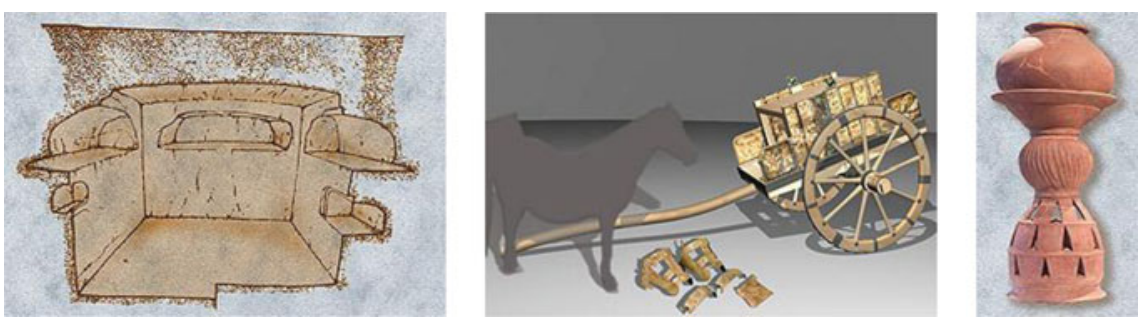

Fig. 18.2 Archaeological context

screens to maximize flexibility and allow experimentation with this same equipment; fixed seats with LCD touch screen panels wired for interactive participation and interconnected to a large screen display.

\subsubsection{Colle del Forno Archaeological Area}

The architectural design was also to include a hypothesis for the linking and integration of the new complex with the archaeological area called Colle del Forno, located on the crest of a hill that dominates the area, represented by a pre-Roman necropolis and currently inaccessible to the public. To relate the building organism with the necropolis, an open-air museum display area was called into play to provide a system of trails and facilities for visiting and reading in experimental ways (Fig. 18.2).

Laboratories constitute a unique challenge for sustainable design because of their intense energy use, stringent health and safety requirements, and complex environmental systems. Because of this, growing public awareness of sustainable design and construction has not gone unnoticed by the scientific community. The U.S. Green Building Council (USGBC), the Leadership in Energy and Environmental Design (LEED) program and the EPA/DOE's Labs21 were considered as guides and organizational tools supporting the sustainable design process for this specific area. From a spatial point of view the building must achieve an appropriate balance between open and closed type laboratories, developed on one or more levels, integrating with other agencies and with the surrounding topography, structured and populated with existing and new vegetation. The results of this Design Studio have shown a panorama of architectural solutions in which these scientific buildings were linked to issues of environmental sustainability and energy savings.

\subsubsection{Program Requirements}

Student projects must include the following components:

- Structured spaces for technology labs. 
- Flexible wireless space for researchers.

- Multimedia center for technology simulations, design and science exhibits.

- Space for meetings and conferences.

- Offices for management of activities.

- Common areas.

- Toilets, a kitchen etc.

\subsubsection{Project Requirements}

Students were required to design a building defined by function rather than style, that can either be characterized as a strong architectural landmark-distinctive of the CNR campus-or as a compositionally light structure, morphologically and most of all ecologically. Technologically, the building must be designed as a living organism, able to generate energy via its own form, mass and volumes, utilizing primarily passive design strategies and systems. High level sustainability can include advanced water recycling systems and natural ventilation, favoring daylit interiors (Fig. 18.3).

\subsection{Results}

The results achieved by the final projects submitted were all of good quality, with a notable percentage of high quality, convincing the faculty to proceed with this teaching method. With regard to the project requirements in terms of sustainability and energy conservation, it is necessary to state that students have shown themselves highly receptive and capable to acquire a new design language, inspired by the themes proposed by the innovative use of bioclimatic strategies and skilful application of materials and vegetation. Even the interiors, which required some degree of design has been developed to the satisfaction of the choices made by the student.

\subsection{Conclusions}

This research shows its originality not only in the approach to teaching sustainability issues, but, of course, in the strategic content of the Green Lab projects themselves and especially in the teaching methodology used, unequivocally confirmed by the value of its results. All areas of the research support the potential for future development and areas of application. 

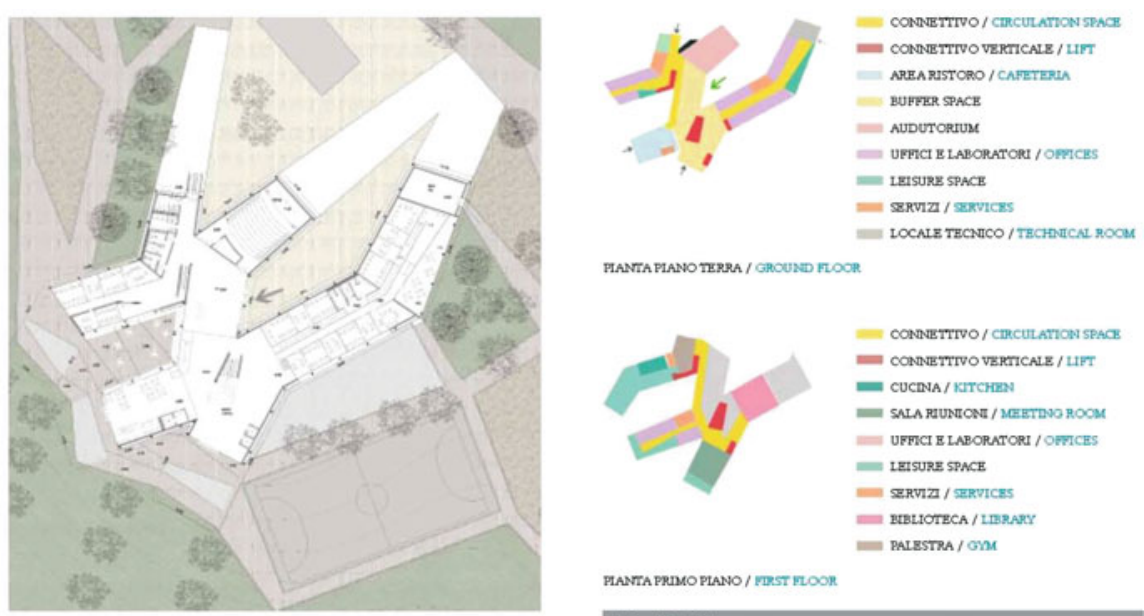

TANTA PIANO TERRA / GROUND HOCR

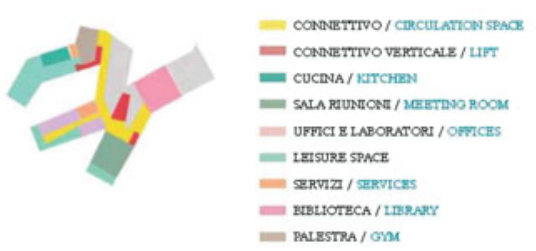

PIANTA PRMMO PTANO / FPST MOOK
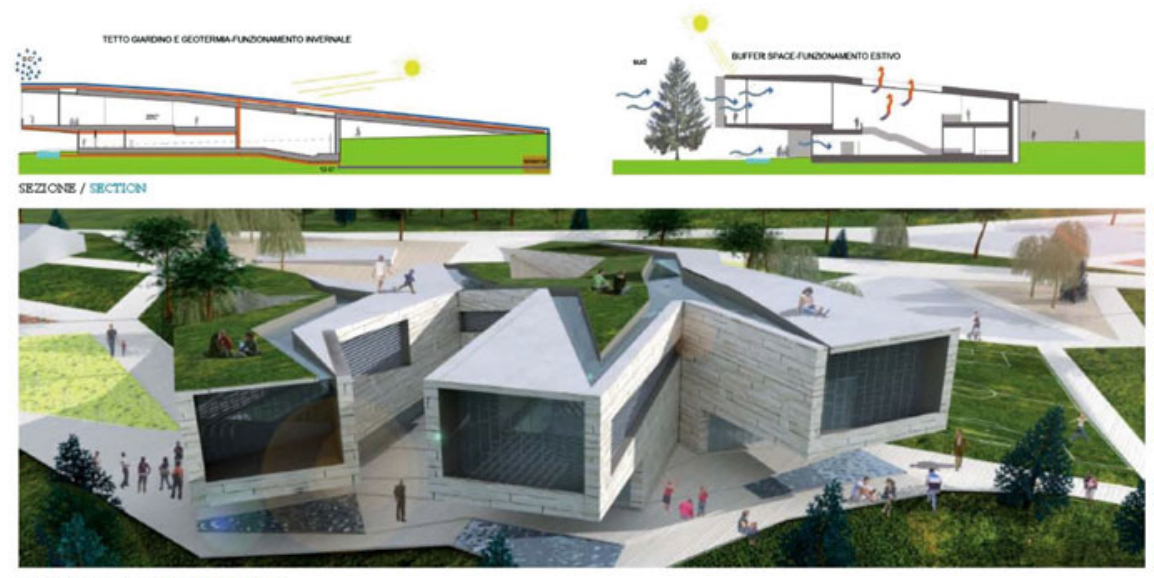

VISTA PROSPETITCA / MOONECTIVE VEW

Fig. 18.3 Sample of student work

\section{References}

1. http://www.diarambiente.it

2. http://architecture2030.org/

\section{Bibliography}

Abdu-Khader MM, Speight JG (2004) The concepts of energy, environment, and cost for process design. Int J Green Energ 1:137-151 
(2008) Area n.99, Save energy. In: Rivista di architettura e arti del progetto

Open House International (2008) The quest for zero carbon housing solutions - La domanda di abitazioni a zero emissioni. 33(3)

Bell B (2004) Good deeds, good design. Community service through architecture. Princeton Architectural Press, New York

Benyus JM (2002) Biomimicry. Innovation inspired by nature. Harper Perennial

Brown LR (2008) PIANO B 3.0 Mobilitarsi per salvare la civiltà. Ambiente

Brown LR (2010) PIANO B 4.0 Mobilitarsi per salvare la civiltà, Ambiente

Butera FM (2007) Dalla caverna alla casa ecologica, storia del comfort e dell'energia. Ambiente

Coyle D (2012) Economia dell'abbastanza Gestire l'economia come se del futuro ci importasse qualcosa. Edizione Ambiente

Dall’Ò G, Gamberale M, Silvestrini G (2008) Manuale della certificazione energetica degli edifici. Norme, procedure e strategie d'intervento. Ambiente, Milano

Falcione M (2008) Diritto dell'Energia - Fonti rinnovabili e risparmio energetico. In: Collana "Quaderni dell'AIEE" (Associazione Italiana Economisti dell'energia)

Fassi A, Maina L (2006) L'isolamento ecoefficiente. Ambiente, Milano

Friedman TL (2008) Hot, flat, and crowded. Why we need a green revolution - and how it can renew America. Straus \& Giroux, Farrar

Goleman D (2009) Ecological intelligence: how knowing the hidden impacts of what we buy can change everything. Broadway Books, New York

Henderson H, Ikeda D (2005) Cittadini del Mondo, L'impegno di ognuno per costruire un futuro sostenibile. Sperling \& Kupfer

Hopkins R (2009) Manuale Pratico della Transizione, Arianna

Johnson, Bart R, Hill K (2001) Ecology and design, frameworks for learning. Island Press, Washington, DC

Karr JR (2002) What from ecology is relevant to design and planning? In: Johnson BR, Hill K (eds) Ecology and design: frameworks for learning

Kreith F, Kreider J (1978) Principles of solar engineering. Hemisphere-McGraw-Hill, New York

Krugman P (2010) Un'altra economia. In: Internazionale, vol 843. pp 23/29

Lovelock J (2006) La rivolta di Gaia. Rizzoli editore

Mercalli L (2011) Prepariamoci. Un piano per salvarci, Chiare Lettere

Moggridge B (2007) Designing interactions. MIT Press, Cambridge, MA

Orr DW (2009) Down to the wire. Oxford University Press

Pallante M (2009) La decrescita felice, Per la decrescita felice

Pallante M (2009) La Felicità Sostenibile, Rizzoli

Palleroni S, Merkelbach E, Eichbaum C (2004) Studio at large, architecture in service of global communities. University of Washington Press, Seattle

Sassi P (2008) Strategie per l'architettura sostenibile. I fondamenti di un nuovo approccio al progetto, Ambiente

Shiva V (2002) Terra Madre - Sopravvivere allo sviluppo, UTET Libreria

Sinclair C, Stohr K (2006) Design like you give a Damn. Architectural responses to humanitarian crises. Architecture for humanity

Steffen A (2006) Worldchanging. A user's guide for the 21st century. Henry N. Abrams Inc., New York

Stern N (2009) Un piano per salvare il pianeta. Feltrinelli

Todd, Nancy Jack \& John (2007) Progettare secondo natura. Eleuthera, Milano

Villeneuve, Claude-Richard, François (2008) Vivere i Cambiamenti Climatici. Muzzio

Ward B (1976) La casa dell'uomo, come inventare la città futura. Arnoldo Mondadori

Weisman A (2008) Il mondo senza di noi. Che cosa succederebbe sul nostro pianeta con la scomparsa dell'uomo? Einaudi Stile libero extra

Williams DE (2007) Sustainable design, ecology, architecture, and planning

Worldwatch Institute (a cura di Gianfranco Bologna) (2011) State of the world 2011: Nutrire il pianeta. Ambiente 
http://architecture2030.org/

http://www.diarambiente.it

http://www.kyotoclub.org/prossimi-eventi/2012-giu-5/smart_cities/docId=2827

http://www.genitronsviluppo.com/

MOBILE-SCHOOL: La Scuola Costruisce la Scuola 